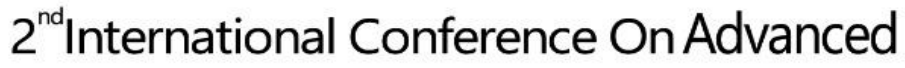 Research in HUMANITIES
}

30 october - 01 November, 2019

MILAN, ITALY

\section{Freedom to Have no Religion in Indonesia and its Legal Impact}

\author{
Muchammad Ichsan $^{1}$ and Nanik Prasetyoningsih ${ }^{2}$ \\ ${ }^{1}$ Master of Law Program, ${ }^{2}$ Faculty of Law, Universitas Muhammadiyah Yogyakarta \\ Jl. Brawijaya, Tamantirto, Kasihan, Bantul, Yogyakarta, Indonesia 55183
}

\begin{abstract}
Indonesia's population consists of a variety of ethnicities and cultures. Therefore, it is not surprising if they also have various kinds of religions and beliefs. Some of them even have no religion at all. This study aims to examine whether Indonesian law allows people to have no faith or not. Besides, this study outlines the legal impact of not having religion and belief in Indonesia. For these purposes, this study is designed to be qualitative and uses normative legal research methods. The research found that Indonesia has rules regarding religious freedom. People have the right to embrace whatever religion they want, especially the six official religions, namely, Islam, Christianity, Catholicism, Buddhism, Hinduism, and Confucianism. They also have the right to worship according to the teachings of their religion. However, according to a strong opinion, the right to recognize any religion does not mean the freedom not to be religious. Thus, Indonesia banned atheism based on several arguments. The indigenous belief, although not a religion, is not atheism. The indigenous belief is justified and has legal protection in Indonesia because it has been there for a long time. The legal impact for those who do not have religion is that they will face difficulties in obtaining their rights, such as in terms of education, marriage, and financial matters.
\end{abstract}

Keywords: Freedom of Religion, Atheism, Indigenous Believe, Indonesia.

\section{Introduction}

Until now, the issue of religious freedom is still a complicated and complex problem in Indonesia. Starting from the notion of religious freedom and its limitations, the formulation of regulations and the implementation of these regulations in the field still leaves big problems. As a result, conflicts often occur between followers of different religions and even intra-followers of a religion. These conflicts happen in several forms, such as misguided judgments of a particular religious group, destruction of places of worship, discriminatory treatment of officials against 


\section{Earhoonf}

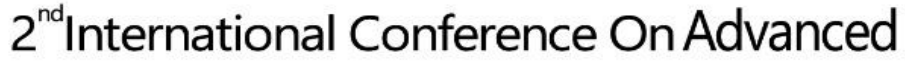 Research in HUMANITIES}

30 october - 01 November, 2019

MILAN, ITALY

followers of a religion or belief, expulsion of followers of a religion or belief in the community, and many lives lost due to differences in perceptions regarding religious freedom.

Some researchers define religious freedom as the freedom to embrace the religion they like and practice the teachings of their faith. Some researchers add, including in it, free to form a belief (Sopyan, 2015). And some others added, including being free to move from religion to another religion (Zainuddin, 2009). However, they agreed that the desecration of faith included not in religious freedom (Triyanta, 2013).

Although there are only six officially recognized religions in Indonesia, namely Islam, Christianity, Catholicism, Hinduism, Buddhism and Confucianism, based on the Decree of the President of the Republic of Indonesia No. 1 / PNPS in 1965, the population is still justified in exercising religious rights, believing in beliefs, stating thoughts and attitudes according to his conscience. Thus they may have whatever religion they want besides the six official religions above.

Residents may even make interpretations and religious activities that deviate from the teachings of a religion, insofar as they are for themselves. However, if he recounts, advocates or seeks general support for interpreting and religious activities that deviate from the points of his religious teachings, then it is prohibited because it has injured the basic teachings of the religion.

Freedom of religion, in general, can be viewed from two angles; First, internal dimensions. Second, external dimensions. Included in the inner aspect is liberty of conscience, which is the freedom of the heart to choose and embrace a religion that is preferred. This freedom is absolute, must not be restricted while those who enter the external dimension are freedom to express religious teachings, freedom to form religious associations, and freedom to institutionalize spiritual lessons. This external dimension is relative, in the sense that the right to express religious beliefs, the right to systematize religious teachings and the right to form religious associations are closely related to other social institutions such as law and politics (Hafsin, 2010). Thus it can be said that religion is a personal choice, but the actualization, expression, and practice of faith in the public space is an integral part of social life. The state must be present in the public sphere, not as a form of State intervention in the freedom to believe and carry out religious teachings, but is needed to maintain an orderly, safe and peaceful society.

How about the freedom to have no religion in Indonesia? Is the Indonesian population justified in not having a religion or following atheism which does not believe in God? What about the indigenous belief whose followers believe in the Almighty God, but the indigenous belief is considered not including religion in Indonesia? And what is the legal impact of people who have no faith? These things will be the object of the following study. 


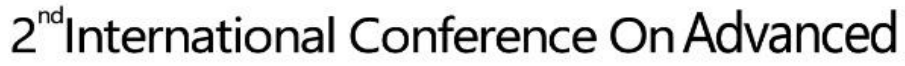 Research in HUMANITIES}

30 october - 01 November, 2019

MILAN, ITALY

\section{Method}

The research method used is a normative legal research method. Normative legal research was conducted to explore and review legislation regarding freedom of religion and belief, so it ascertained the justification for freedom from religion in Indonesia. This study used a qualitative approach. The method of collecting data used in library research. The data in this study are secondary, in the form of primary legal materials, secondary legal materials, and tertiary legal materials. The data analysis used is descriptive qualitative, and explanatory. The results of the study will be in a narrative that describes and explains the object under study.

\section{Analysis and Discussion}

There is a difference between freedom of religion and freedom from religion. In terms of religious freedom, Indonesia has a set of laws and regulations governing religious freedom. The rules and regulations are (1) the 1945 Constitution, (2) Law No. 39 of 1999, (3) Law No. 12 of 2005, (4) Determination of the President of the Republic of Indonesia Number 1 / PNPS in 1965, and (5) Joint Regulations of the Minister of Religion and Minister of Home Affairs No. 9 of 2006, No. 8 of 2006. And in terms of freedom from religion, there are no strict laws and regulations that regulate it.

The first and foremost legislation governing religious freedom is the 1945 Constitution. Article 28E paragraph (1) it reads: "Everyone is free to embrace religion and worship according to his religion ..." And paragraph (2) reads: "Everyone has the right to freedom of belief, express their thoughts and attitudes according to their conscience." These Articles affirm that every person in Indonesia has the right to embrace the religion he likes and worship according to his religious teachings because it is a human right.

The articles concerning the right to religion and worship above are then strengthened by other articles which affirm that religious freedom include rights that cannot be reduced under any circumstances and there is no discrimination against the enforcement of these rights. Article 28I paragraph (1) reads: "The right to life, the right not to be tortured, the right to freedom of thought and conscience, religious rights, the right not to be enslaved, the right to be recognized as a person before the law, and the right not to be prosecuted on the basis of retroactive laws are human rights which cannot be reduced under any circumstances." Then paragraph (2) reads: "Every person has the right to be free from discriminatory treatment on any basis and has the right to receive protection against such discriminatory treatment". 


\section{Earhconf}

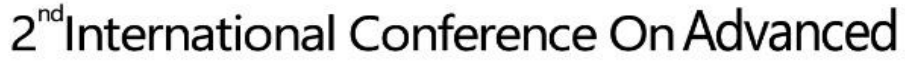 Research in HUMANITIES}

30 october - 01 November, 2019

MILAN, ITALY

More than that, the State must guarantee and protect the right to religion and worship carried out by the population. Article 29 paragraph (2) reads: "The State guarantees the independence of each resident to embrace his religion and to worship according to his religion and belief."

The other legislation is Law No. 39 of 1999 concerning Human Rights. Article 22 paragraph (1) of this Law reads: "Every person is free to embrace his religion and to worship according to his religion and his beliefs." Furthermore, paragraph (2) reads, "The State guarantees the freedom of every person to embrace his religion and to worship according to his religion and his beliefs." Paragraph (1) above confirms that the right to freedom of religion and worship according to their faith is a human right while paragraph (2) emphasizes that the state must guarantee the protection, respect and fulfilment of these rights for everyone in Indonesia.

Another article also stated that everyone has the right to receive protection for their human rights, including the right to religion and belief without discriminatory treatment. Article 3 paragraph (3) reads: "Everyone has the right to the protection of human rights and basic human freedoms, without discrimination." Besides, the next article emphasizes that the right to freedom of religion is a right that cannot be reduced under any circumstances. Article 4 reads: "The right to life, the right not to be tortured, the right to personal freedom, mind and conscience, religious rights, the right not to be enslaved, the right to be recognized as a person and equality before the law, and the right not to be prosecuted on a legal basis retroactive are human rights that cannot be reduced under any circumstances and by anyone ".

Furthermore, the third legislation governing religious freedom is Law No. 12 of 2005 concerning Civil and Political Rights. The right to freedom of religion and belief and practice religion and beliefs are protected, and there must be no coercion. Article 18 paragraph (1) which reads: "Every person has the right to freedom of thought, conscience, and religion. This right includes the freedom to embrace or accept a religion or belief in his own choice, and freedom, both individually and together with others, and whether in a public or closed place, to practice his religion or belief in religious activities, obedience, practice, and teaching ". In paragraph (2) it reads: "No one may be forced to interfere with his freedom to adhere to or accept a religion or belief according to his choice."

According to article Law No. 12 of 2005 above, the right to freedom of religion and belief is the right of every person. States Parties, including the Indonesian government, must guarantee the protection, respect, and fulfilment of these rights. States parties must also prohibit - through legislation - all discriminatory actions and all actions that encourage hatred in the name of religion. Article 20 paragraph (2) reads: "Any action that promotes hatred based on nationality, race or religion which is an incitement to discrimination, hostility or violence must be prohibited by law." 


\section{Earhconf}

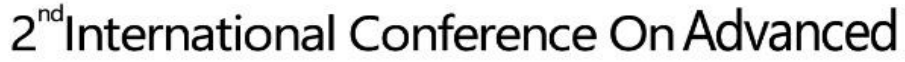 Research in HUMANITIES}

30 october - 01 November, 2019

MILAN, ITALY

Because of the importance of freedom of religion, this Law places the right to freedom of religion and worship according to religious beliefs in rights that must not be revoked and should not be discriminated against under any conditions. Article 4 paragraph (1) reads: "In public emergencies that threaten the life of the nation and the existence of such an emergency has been officially announced, States Parties to the Covenant can take derogate of their obligations under this Covenant, insofar as it is demanded by the emergency, provided that these efforts do not conflict with the obligations of the States Parties under international law, and do not involve discrimination based on race, colour, sex, language, religion and social origin."

The fourth legislation is the Determination of the President of the Republic of Indonesia Number 1 / PNPS of 1965 concerning the Prevention of Abuse and or Blasphemy of Religion. The explanation of Article 1 stated that the religion embraced by almost all the population in Indonesia is six, namely Islam, Christianity, Catholicism, Hinduism, Buddhism, and Confucianism. Indonesia does not prohibit other religions, such as Jews, Zarasustrian, Shinto, Taoism, and they get full guarantees as given by the 1945 Constitution Article 29 paragraph (2), provided that they do not violate the provisions contained in this regulation or other laws and regulations. And the Government tries to channel the indigenous belief towards the Almighty Godhead.

The fifth legislation is the Joint Regulation of the Minister of Religion and Minister of Home Affairs No. 9 of 2006, No. 8 of 2006 concerning Guidelines for the Implementation of Duties of Regional Heads / Deputy Regional Heads in the Maintenance of Religious Harmony, Empowerment of Religious People's Forum, and Establishment of Houses of Worship. As the name implies, this Joint Regulation regulates the establishment of places of worship for each believer. This Joint Regulation supersedes the Joint Decree (SKB) of the Minister of Religion and Minister of Home Affairs No. 1 / BER / MDN-MAG in 1969 concerning the Establishment of Houses of Worship which were deemed not to have regulated in detail the procedures for establishing places of worship so as to cause many closures, destruction and attacks on places of worship.

Of the five regulations above found that freedom of religion and belief in Indonesia is not absolute. Although in some of the above laws it is stated that freedom of religion, faith and carrying out religious teachings and beliefs are rights that cannot be reduced under any circumstances, but from the other side it is clearly stated that the law limited freedom. The purpose of restricting these freedoms is to guarantee the rights and freedoms of others and to provide justice, security, and public order.

Article 28J Paragraph (2) of the 1945 Constitution states: "In exercising their rights and freedoms, each person must submit to the restrictions stipulated by law with the sole purpose of guaranteeing, recognition, and respect for the rights and freedoms of others and fulfil demands 


\section{Earhconf}

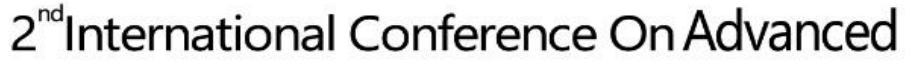 Research in HUMANITIES}

30 october - 01 November, 2019

MILAN, ITALY

fair in accordance with moral considerations, religious values, security, and public order in a democratic society."

Article 73 of Law No. 39 of 1999 concerning Human Rights also limits religious freedom by stating: "The rights and freedoms outlined in this Law can only be limited by and based on law, solely to guarantee the recognition and respect for human rights and fundamental freedoms of others, morality, public order, and the interests of the nation."

The freedom to practice religion and belief is also limited in Article 18 paragraph (3) of Law No. 12 of 2005 which reads: "The freedom to practice one's religion or belief can only be limited by legal provisions, which are needed to protect the security, order, health or morals of the people or the fundamental rights and freedoms of others."

Another proof of the restrictions on freedom of religion and belief is that the Government only recognizes six official religions in Indonesia, although Indonesia permitted other religions as stated in the explanation of the Determination of the President of the Republic of Indonesia Number 1 / PNPS in 1965.

This restriction makes M. Syafi'ie question how religious freedom, which is a right that cannot be reduced under any circumstances, is limited by law? (Syafi'ie, 2011). This limitation is not something strange because what is limited is freedom of expression that is closely related to public life so that there is no friction and security is created. Moreover, the international community also recognizes restrictions on religious freedom by law as stated in Article 18 of the International Covenant on Civil and Political Rights or the International Covenant on Civil and Political Rights (ICCPR) which reads: 1. Everyone shall have the right to freedom of thought, conscience, and religion. This right shall include freedom to have or to adopt a religion or belief of his choice, and freedom, either individually or in community with others and in public or private, to manifest his religion or belief in worship, observance, practice, and teaching. 2. No one shall be subject to coercion, which would impair his freedom to have or to adopt a religion or belief of his choice. 3. Freedom to manifest one's religion or beliefs may be subject only to such limitations as are prescribed by law and are necessary to protect public safety, order, health, or morals or the fundamental rights and freedoms of others. 4. The States Parties to the present Covenant undertake to have respect for the liberty of parents and, when applicable, legal guardians to ensure the religious and moral education of their children in conformity with their convictions.

According to Article 18 paragraph (3) of the Covenant above, freedom of religion and religious teachings must only be limited by law with the aim of protecting: (1) public safety, (2) public order, (3) general health (public health), (4) moral community (public moral) and (5) fundamental rights and freedoms of others.

According to logic and in practice, religious freedom - including in Indonesia - it is impossible to do in absolute terms. Because when it comes to the level of expression, religious 


\section{Earhoonf}

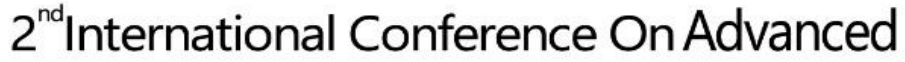 Research in HUMANITIES}

freedom will be relative. This relativism is not because religious freedom is betrayed, but because of the need to harmonize the rights of all citizens (Hafsin, 2010). If freedom is carried out in such a way that it harms others or makes others not have freedom, then that means doing dictatorship in the name of freedom and can ignite what is called "blasphemy" (Triyanta, 2013).

Of the five laws and regulations above also found that voluntarily exchanging a religion with another religion was justified in Indonesia. Including apostasy or leaving Islam to embrace another faith. Apostasy is also justified in Indonesia if it is carried out without coercion or lure, while it is a criminal whose sentence is substantial according to Islamic criminal law (Ichsan and Susila, 2006). According to Zainuddin, religious freedom means free to embrace a recognized religion in Indonesia (Hinduism, Buddhism, Christianity, Catholicism, and Confucianism), free to move from one religion to another, and free to express and express the teachings of the faith that he embraces." (Zainuddin, 2009).

What about the right not to have a religion, is this justified in Indonesia? None of the laws and regulations concerning religious freedom above mentions the prohibition on non-religion at all explicitly. Because there is no firmness, at least there are two opinions regarding whether or not atheism in Indonesia is allowed as follows:

In the Determination of the President of the Republic of Indonesia Number $1 /$ PNPS in 1965 Article 4 which is entered into Article 156A of the Criminal Code stated: "Sentenced to imprisonment for a maximum of five years whoever intentionally issues feelings and / or acts; $a$. which is essentially hostility, abuse or desecration of the status of religion adopted in Indonesia; $b$. with the intention that people do not adhere to any religion, which is based on the One Godhead." If Article 156A KUHP letter b above noted, it will be found that what is prohibited is inviting other people not to adhere to any religion. Thus, if a person adheres not to any religion or does not encourage others to do the same thing, then he is allowed and not subject to criminal activity.

Abu Hafsin (2010) corroborates this by quoting Koshy who details religious freedom into four main aspects: liberty of conscience, freedom to express religious beliefs, freedom of religious association and freedom to institutionalizing sovereignty of religious institutionalization. Freedom of conscience is the most fundamental and absolute right in a person. That is, not inalienable from someone. Because freedom of conscience is the absolute right, everyone must have the freedom to choose and not choose a religion.

Besides, personal beliefs are an excellent value. Therefore, if there is someone who believes that God does not exist, then the state must guarantee, recognize, and protect its right to godlessness. At the level of religious conscience, no one - including the State - can hinder this freedom of conscience. Pancasila only limits religious freedom at expressional levels (Hafsin, 2010). 


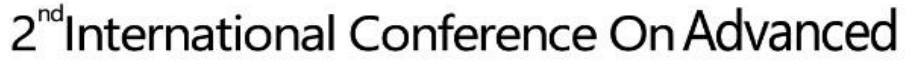 Research in HUMANITIES}

Meanwhile, according to Zainuddin (2009), religious freedom in the Indonesian context has been regulated in the law as "free to choose and embrace a certain religion," not free from nonreligion. Thus, Indonesia prohibited atheism or not believing in God or having no religion at all. It is because Indonesia is a country based on Pancasila. In the first principle of Pancasila, it is stated: Godhead the One. This principle emphasized that belief in God Almighty is the prime base of Indonesia. Also, in Article 29 paragraph (1) of the 1945 Constitution, it is expressly stated: "The State is based on the One Godhead." Although Indonesia is not a religious State, religious life, and worship according to each religion and belief over there are protected by law (Alpizar, 2015).

On the other hand, atheism is very close to communism / Marxist-Leninism which since 1966 until now Indonesia still bans it. The prohibition was found in the Republic of Indonesia MPRS TAP Number XXV / MPRS / 1966 of 1966 concerning the Dissolution of the Indonesian Communist Party, Statement as a Prohibited Organization in the Entire Territory of the Republic of Indonesia for the Indonesian Communist Party and Prohibition of Any Activities to Distribute or Develop Communism / Marxism-Leninism. As understood and truly happened in Indonesian history, communism is a doctrine that does not care about religion and even hates religion and alienates religion in all their activities and movements. In the explanation of the TAP MPRS above it is stated that the notions or teachings of Communism / Marxism-Leninism are contrary to the principles and joints of the life of the Indonesian people who are godly and religious.

According to Muhammad Tahir Azhary, Professor of Faculty of Law UI in his book "Negara Hukum," Indonesia has a concept called the Concept of the State of Pancasila Law. Its characteristics are: (1) The close relationship between religion and the State, (2) rests on the One Godhead, (3) religious freedom in a positive sense, (4) atheism and communism are prohibited, and (5) the principle of kinship and harmony (Azhary, 1992). The purpose of the third characteristic of religious freedom in the positive sense is the freedom to choose the liked religion and carry out its teachings, not the freedom to choose not to have faith at all. The fourth characteristic then confirms this that atheism or not believing in God and communism are prohibited, and Indonesia does not give the right to live because they are contrary to the Pancasila.

In line with the above thoughts, according to Khotimah (2014), religion has a significant role in Indonesia. It is because Indonesia is a "religion" country, in the sense that Pancasila as the basis of the state insists that there should be no religious people in Indonesia.

If Indonesia banned atheism, then what about the indigenous belief? Didn't the followers of the indigenous belief have no religion? The indigenous belief has existed in Indonesia since the beginning of the 20th century. For example, the Hardosuporo sect was founded by Kusumowidjitro in 1913 in Purworejo, and the Sumarah faith line was founded by Sukinohartono who claimed to have received Sumarah's revelation in 1935 (Stange, 2009). 


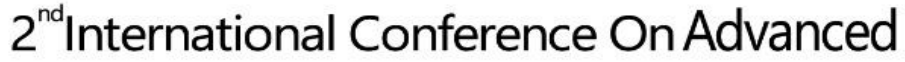 Research in HUMANITIES}

The existence of the indigenous belief is on and off from time to time. It is because the community and also the State still does not fully recognize the indigenous belief until now. There are still tensions or conflicts between religious people, which in this case are Muslims like the majority of the population with adherents of indigenous belief which amounts to around 8 million people spread throughout Indonesia (Ministry of Culture and Tourism, 2003).

In its development, the followers of the various indigenous belief tried hard to get official recognition from the State. Finally, they succeeded in obtaining the legalization of the State so that it has an official name: "Belief in the One and Only God" since the 1973 General Assembly of the People's Consultative Assembly (MPR RI, 1973) and strengthened in the 1978 MPR General Session (MPR RI, 1978).

The Director-General of Culture defines "Belief in the One and Only God" as: "Spiritual culture that consists of great guidance in the form of behavior, law and sacred knowledge, which is shared by its adherents with a conscience in the awareness and belief in God Almighty, by cultivating perseverance and inner vigilance and refining character in the social order towards mental cleanliness and spiritual maturity, in order to achieve prosperity and perfection of life in this world and in the eternal realm." (Director-General of Culture, 1980).

The indigenous belief is unique. The state does not recognize it as a religion (based on the Indonesian Minister of Religion Instruction Number 4 of 1978 concerning Policy on Beliefs), but only as "spiritual culture," because it does not have religious characteristics such as scriptures, prophets, laws, and others (Matdawam, 1984). The followers also do not want people to categorize the indigenous belief like religion. However, that does not mean they do not believe in God. So they were not religious, and at the same time, they were not atheists who did not believe in God at all. However, because they were already in Indonesia long before independence, they were placed in the guidance of the Ministry of Education and Culture, not the Ministry of Religion like the other six official religions.

The latest development, the Constitutional Court has made Decision Number 97 / PUUXVI / 2016 concerning Testing Law No. 23 of 2006 concerning Population Administration as amended by Law No. 24 of 2013 concerning Amendments to Law No. 23 of 2006 concerning Population Administration against the 1945 Constitution, which states that the provisions of Article 61 paragraph (1) and paragraph (2) and Article 64 paragraph (1) and paragraph (5) are related to the emptying of religious columns in the Family Card and electronic Identity Card contrary to the Constitution. The consequence of this Constitutional Court Decision is that the followers of indigenous belief can list their beliefs in the religious column both on the Family Card and the electronic Identity Card.

As such, there should be no more legal problems for the followers of indigenous belief in Indonesia. If they get a legal issue, then it is not because of the laws and regulations, but because 


\section{Corhconf}

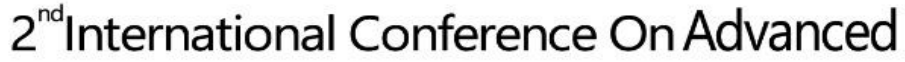 Research in HUMANITIES}

30 october - 01 November, 2019

MILAN, ITALY

the community and individual officers are not ready to implement the Constitutional Court Decision.

From the discussion above, it shows that the State's treatment of atheists is different from the treatment of followers of indigenous belief. Atheists in Indonesia will face several legal impacts and difficulties (Bawono and Kusumasari, 2012).

Among the effects of the law is that if an atheist wants to make a Family Card and electronic Identity Card, then the religious column in the two population documents must be vacated. It is in accordance with Article 64 paragraph (5) Law No. 24 of 2013 which reads: "Population data elements concerning religion as referred to in paragraph (1) for residents whose religion has not been recognized as a religion based on the provisions of legislation or for trustees are not filled, but are still served and recorded in the population database."

As a result, he will face difficulties in managing other documents such as driving licenses, passports, marriage certificates, police records, and others. It causes the loss of his rights as citizens in the fields of education, marriage, welfare, health, politics, and others.

In the case of education, for example, an atheist whose school ranks elementary, middle and high school must take a religious subject from one of the religions recognized by the Government, whether he likes it or not, because in Indonesia the subject of atheism is not taught. In the matter of marriage, an atheist cannot be legally married in Indonesia, because Article 2 paragraph (1) of the Marriage Law of 1974 states that marriage is legal if it is carried out according to the laws of each religion and its beliefs. In economic matters, an atheist will have difficulty when applying for a job because many employers will ask about his faith. In political issues, an atheist must not be a President or Minister or Regional Head because one of the conditions for holding a public office is to fear the Almighty God, and they will swear according to their religion.

Therefore, if an atheist wants to get his rights as an Indonesian citizen, he must be religious with one of the official religions or pretend to embrace one of these official religions. So that their religions are written in the religion column of the Family Card and electronic Identity Card, as which had been experienced by followers of the indigenous belief before the issuance of the Constitutional Court Decision Number 97 of 2016.

\section{Conclusion}

Indonesia has laws and regulations regarding freedom of religion and belief. Even though in the law it is stated that the right to religion and faith is a right that cannot be reduced under any circumstances, but to respect and fulfil the rights of others and to maintain security and public order, the law limits religious freedom. 


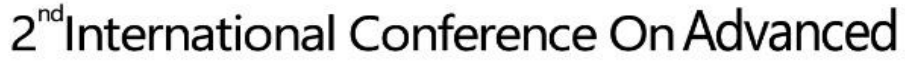 Research in HUMANITIES}

Freedom of religion in Indonesia is in a positive sense. That is, all residents may choose the faith and beliefs they like. Even they may move from one religion to another. However, freedom of religion does not mean the freedom not to embrace any religion because Pancasila which beliefs in God Almighty is the base of the State. Atheists or people who do not have any faith will experience many difficulties and will not get their rights as Indonesian citizens correctly because Indonesia does not recognize the ideology that they adhere to.

\section{Acknowledgement}

This paper is the result of a science project facilitated and funded by the Institute for Research, Publication and Community Service at the Universitas Muhammadiyah Yogyakarta in 2019. Therefore, the researchers appreciated and thanked the director and chancellor.

\section{Reference}

\section{Books}

[1) Azhary, Muhammad Tahir. (1992). Negara Hukum: Suatu Studi tentang Prinsip-Prinsipnya Dilihat dari Segi Hukum Islam, Implementasinya pada Periode Negara Madinah dan Masa Kini. Jakarta: Bulan Bintang.

[2] Director General of Culture. (1980). Keputusan Direktur Jenderal Kebudayaan Nomor: 021/A.1/1980 Tentang Pedoman Pembinaan Penghayat Kepercayaan terhadap Tuhan Yang Maha Esa. Jakarta: Proyek Inventarisasi Kepercayaan terhadap Tuhan Yang Maha Esa Direktorat Pembinaan Penghayat Kepercayaan terhadap Tuhan Yang Maha Esa.

[3] Ministry of Culture and Tourism. (2003). Ensiklopedia Kepercayaan Terhadap Tuhan Yang Maha Esa. Jakarta: Proyek Pelestarian Pengembangan Tradisi dan Kepercayaan.

[4] People's Consultative Assembly of the Republic of Indonesia. (1978). Buku Kedua Alat Sidang Umum Majelis Permusyawaratan Rakyat Republik Indonesia Bulan Maret 1978, Risalah Rapat-rapat Paripurna Badan Pekerja (Rapat Ke- 1 s/d 7: Penjelasan Team XI dan Pemandangan Umum Fraksi-fraksi), Jilid I, Jakarta: Issuance of MPR.

[5] Matdawam, M. Noor. (1984). Pembinaan Akidah Islam. Yogyakarta: Yayasan Bina Karier LP5BIP.

[6] Stange, P. (2009). Kejawen Modern Hakikat Dalam Penghayatan Sumarah, terjemahan Chandra Utama. Yogyakarta: LKiS. 


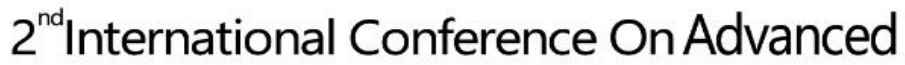 Research in HUMANITIES}

30 october - 01 November, 2019

MILAN, ITALY

\section{Journals}

[1] Alpizar. (2015). Toleransi Terhadap Kebebasan Beragama Di Indonesia (Perspektif Islam). TOLERANSI: Media Komunikasi Umat Beragama, 7(2), 144-145.

[2] Hafsin, A. (2010). Demokrasi di indonesia Antara Pembatasan dan Kebebasan Agama. Analisa, XVII(1), 9-18.

[3] Khotimah. (2014). Agama dan Civil Society. Jurnal Ushuluddin, XXI(1), 121-132.

[4] Sopyan, Y. (2015). Menyoal Kebebasan Beragama Dan Penodaan Agama Di Indonesia. Jurnal Cita Hukum, III(2), 195-212.

[5] Syafi'ie, M. (2011). Ambiguitas Hak Kebebasan Beragama di Indonesia dan Posisinya Pasca Putusan Mahkamah Konstitusi. Jurnal Konstitusi, 8(5), 675-705.

[6] Triyanta, A. (2013). Mencari Benang Me Rah Konstitusional Antara Kebebasan Beragama Dan Penodaan Agama; Dari Konsep Blasphemy Law Hingga Pelarangan Ahmadiyah Dl Indonesia. UNISIA, XXXV(78), 25-33.

[7] Zainuddin, M. (2009). Kebebasan Beragama Dan Demokratisasi Di Indonesia. El-Harakah, 11(2), 172-180.

\section{Online Sources}

[1] Bawono, Adi Condro and Kusumasari, Diana. (2012). Bolehkah Menjadi Ateis Di Indonesia? Available:

https://www.hukumonline.com/klinik/detail/ulasan/lt4f4545a9b77df/bolehkah-menjadi-ateisdi-indonesia-

\section{Legislation}

[1] Indonesian Ministry of Religion Instruction Number 4 of 1978 concerning Policies Regarding the Indigenous Belief.

[2] International Covenant on Civil and Political Rights (ICCPR). Available: https://reaties.un.org/doc/publication/unts/volume\%20999/volume-999-i-14668-english.Pdf

[3] Determination of the President of the Republic of Indonesia Number 1/PNPS in 1965 concerning the Prevention of Abuse and or Blasphemy of Religion.

[4] Joint Regulation of the Minister of Religion and Minister of Home Affairs No. 9 of 2006, No. 8 of 2006 concerning Guidelines for the Implementation of Duties of Regional Heads / Deputy 


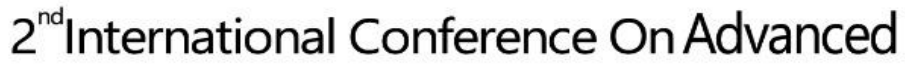 Research in HUMANITIES}

MILAN, ITALY

Regional Heads in the Maintenance of Religious Harmony, Empowerment of Religious People's Forum, and Establishment of Houses of Worship.

[5] Law no. 1 of 1974 concerning Marriage.

[6] Law no. 12 of 2005 concerning Civil and Political Rights.

[7] Law no. 39 of 1999 concerning Human Rights.

[8] Republic of Indonesia MPRS TAP Number XXV / MPRS / 1966 of 1966 Regarding the Dissolution of the Indonesian Communist Party, Statement as a Prohibited Organization in the Entire Territory of the Republic of Indonesia for the Indonesian Communist Party and Prohibition of Any Activities to Distribute or Develop Communism / Marxism-Leninism.

[9] The 1945 Constitution.

[10] The Decision of the Constitutional Court Number 97 / PUU-XVI / 2016 concerning Testing Law No. 23 of 2006 concerning Population Administration as amended by Law No. 24 of 2013 concerning Amendments to Law No. 23 of 2006 concerning Population Administration. 